\title{
Methodology of in situ grazing experiments: evaluation of a new vital dye for preparation of fluorescently labeled bacteria
}

\author{
Slava S. Epstein*, Jeffrey Rossel \\ Marine Science Center, Northeastern University, East Point, Nahant, Massachusetts 01908, USA
}

\begin{abstract}
A new fluorescent dye, cyanoditolyl tetrazolium chloride (CTC), is suggested for use in grazing studies to prepare fluorescently labeled bacteria (FLB). As food tracers, CTC-stained bacteria appeared to have advantages over FLBs prepared in accordance with previously published protocols. The CTC is a vital dye, non-toxic to the examined bacteria; in our study, the CTC-stained bacteria grew at the same rate as non-stained bacteria. This is an advantage over the commonly used DTAF-employing staining protocol, which results in heat-killed or immobilized prey particles. The CTC-stained bacteria were not toxic to the studied bacterial grazers; a test ciliate grew on FlBs at the same rate as with non-stained prey. The CTC-stained bacteria fluoresced bright red as opposed to the green fluorescence produced by other protocols. This made it easier to distinguish and count the consumed tracers inside protozoan and, potentially, metazoan grazers, both of which appeared green upon glutaraldehyde fixation. CTC-stained bacteria were compared to other food tracers (FLBs stained with fluorescent dyes according to previously published protocols as well as fluorescent latex microspheres) in grazing experiments. The former were consumed by a test bacterivorous ciliate at rates 2.5 - to 4 -fold higher than the latter. Two factors may be responsible for these rates. First, CTC-stained bacteria might better mimic the extant prey. Second, ingested CTC-stained bacteria might be easier to count due to the color of their fluorescence, contrasting with the glutaraldehyde-induced fluorescence of the grazers.
\end{abstract}

KEY WORDS: Bacterivory · Fluorescence - Live staining · Grazing technique

\section{INTRODUCTION}

Trophic interactions between aquatic protozoa and bacteria have been suggested to play a pivotal role in controlling bacterial dynamics (Azam et al. 1983). In the water column, the importance of protozoan grazing on bacteria has been proven beyond doubt (Fenchel 1982, Sherr \& Sherr 1984, McManus \& Fuhrman 1988. Pace 1988). Though in benthos the evidence for grazing balance of bacterial production is controversial (Kemp 1990), the overall significance of predator-prey interactions between aquatic protozoa and bacteria appears indisputable (Kemp 1988, Epstein \& Shiaris 1992b, Hondeveld et al. 1992, Starink et al. 1994). Considering how essential trophic relations are between bacteria and their grazers, improvements in research

•E-mail: sepstein@lynx.dac.neu.edu techniques to quantify those relations may be quite important.

Several different approaches for examining protozoan grazing on bacteria have been suggested and tested. The most widely used technique employs fluorescently labeled bacteria (FLBs) as food tracers; epifluorescence microscopy reveals these tracers as they accumulate in the digestive vacuoles of the grazer (Sherr et al. 1987). Crucial advantages of the technique are (1) grazing experiments are short; (2) sample manipulations are minimized; (3) under certain conditions, protozoan grazers can be identified; (4) a range of ecophysiological questions can be addressed (Sherr \& Sherr 1993). However, the existing protocols have certain disadvantages due to the nature of currently employed fluorochromes (Monger \& Landry 1992, González et al. 1993a). Most importantly, cultured bacteria are predominantly used to prepare labeled prey, in part because the employed dyes are rather non- 
specific and therefore stain too many detrital particles in fields samples. Secondly, the color of labeled prey fluorescence (green) coincides with the color of preservative-induced fluorescence of the grazer (green) which may make it difficult to enumerate small ingested bacteria. This problem is most pronounced in the case of sediment protozoan and all micrometazoan bacterivores characterized by high intensities of this induced fluorescence. The present paper describes a new vital fluorescent dye that, for heterotrophic bacterivores, appears to be superior for preparation of fluorescently labeled prey for grazing experiments.

\section{MATERIAL AND METHODS}

Live fluorescent staining. We tested the ability of several vital fluorescent dyes to stain bacteria in a way suitable for use in grazing experiments. In all cases, the source of bacteria was marine intertidal sand (see below).

Fluorescein isothiocyanate (FITC; Sigma, St. Louis, MO, USA) was used at 2 final concentrations: $100 \mu \mathrm{g}$ $\mathrm{ml}^{-1}$ in either $40 \mu \mathrm{g} \mathrm{ml}^{-1}$ of dithioerythritol (Monger \& Landry 1992, González et al. 1993a) or in carbonate/ phosphate saline (Sherr \& Sherr 1993) and $10 \mathrm{ug} \mathrm{ml}^{-1}$ in either $4 \mu \mathrm{g} \mathrm{ml}^{-1}$ of dithioerythritol or carbonate/ phosphate buffer saline (see above references). Two incubation times were employed: overnight (Monger \& Landry 1992, González et al. 1993a) and 10 to $15 \mathrm{~min}$ (Sherr \& Sherr 1993). Cyanoditolyl tetrazolium chloride (CTC, Polysciences, Inc., Warrington, PA, USA) was used at 3 final concentrations: 5 (manufacturer suggested), 2.5, and $0.5 \mathrm{mM}$. Incubations were $1,2,4 \mathrm{~h}$ and overnight at either room temperature $\left(22^{\circ} \mathrm{C}\right)$ or $28^{\circ} \mathrm{C}$ (Rodriguez et al. 1992). Hydroethidine (HE, Polysciences, Inc.) was used at the concentration suggested by the manufacturer [stock solution ( $7 \mathrm{mg} \mathrm{ml}^{-1}$ ) in $\mathrm{N}, \mathrm{N}$ dimethylacetamide (Polysciences, Inc.), final concentration $14 \mu \mathrm{g} \mathrm{ml}^{-1}$ ] with $0.5,1$, and $2 \mathrm{~h}$ incubation times. 2', 7'-bis(2-carboxyethyl)-5(6)-carboxyfluoresceinacetoxymethylester (BCECF-AM, Sigma) was used following its molecular biological applications (Dr A. Neifach pers. comm.) at $1 \mu \mathrm{g} \mathrm{ml}^{-1}$ final concentration [stock solution $50 \mathrm{\mu g} \mathrm{ml}^{-1}$ in dimethyl sulfoxide (Sigma)].

Bacterial growth experiment. Bacteria were obtained from marine tidal flat sandy sediments and extracted according to Epstein \& Rossel (1995). Briefly, $0.5 \mathrm{~cm}^{3}$ surface sediment samples were sonicated $(3 \times$ 60 s) by an ultrasonic cell disrupter (Branson S-125, $100 \mathrm{~W}$ nominal power output) equipped with a $5 \mathrm{~mm}$ tapered microtip vibrating at $109 \mu \mathrm{m}$ amplitude. Samples were kept on ice to prevent overheating. Upon sonication, dislodged bacteria were washed from sediments with filter-sterilized $(0.2 \mu \mathrm{m}$ pore-size filters) and autoclaved sea water (hereafter called particlefree water, PFW). Once removed, the bacteria were lightly centrifuged $(500 \times g$ for $5 \mathrm{~min})$ to sediment detrital particles, filtered through $3.0 \mu \mathrm{m}$ pore-size filters to remove the remaining detritus, and then concentrated by pelletizing at $13600 \times \mathrm{g}(15 \mathrm{~min})$ followed by resuspension in PFW.

The bacterial suspension was divided into 2 parts. The experimental fraction was stained with CTC ( $0.5 \mathrm{mM}$ final concentration, $2 \mathrm{~h}$ staining time). Upon staining, the bacteria were washed from the dye by repetitive centrifugation/resuspension in PFW (3 cycles). The bacterial suspension was vigorously shaken and lightly sonicated (three $1 \mathrm{~s}$ bursts) to break the bacterial clumps; the remaining clumps were eliminated by filtering the suspension through $3 \mu \mathrm{m}$ poresize polycarbonate filters (Poretics, Livermore, CA, USA). The control fraction remained unstained but underwent the same centrifugation/resuspension/sonication/filtration treatment as the CTC-stained bacteria. Aliquots of experimental and control bacterial suspensions were added to $10 \mathrm{ml}$ of marine broth (Difco Laboratories, Detroit, MI, USA) in $50 \mathrm{ml}$ Erlenmeyer flasks. Flasks were incubated, without shaking, at room temperature $\left(22^{\circ} \mathrm{C}\right)$ and under a $16 \mathrm{~h} \mathrm{light} / 8 \mathrm{~h}$ dark regime. Samples were taken for bacterial enumeration, preserved with formaldehyde ( $4 \%$ final concentration), and stained with 4',6-diamidino-2-phenylindole (DAPI; Sigma) after Porter \& Feig (1980) as modified by Schallenberg et al. (1989) (15 min at $5 \mu \mathrm{g}$ $\mathrm{ml}^{-1}$ final concentration). Bacteria were concentrated on $0.2 \mu \mathrm{m}$ pore-size black polycarbonate filters (Poretics) and counted $(1250 \times)$ under Leitz Dialux 20 or Zeiss Axiophot microscopes equipped for epifluorescence [Leitz filter block 513410 (340 to $380 \mathrm{~nm}$ excitation filter, $400 \mathrm{~nm}$ beam splitter, and $430 \mathrm{~nm}$ barrier filter); Zeiss filter block 9108460094 ( $365 \mathrm{~nm}$ excitation filter, $400 \mathrm{~nm}$ beam splitter, and $450 \mathrm{~nm}$ barrier filter)]. On each filter, no fewer than 200 cells were counted in at least 15 microscopic fields. Both the experiment and the control were run in triplicate.

Grazing experiment. A grazing experiment was conducted to examine the rates of protozoan consumption of (1) CTC-stained bacteria, (2) 5-([4,6-dichlorotriazin2-yllamino)fluorescein (DTAF; Sigma) stained bacteria, (3) FITC-stained bacteria and (4) fluorescent latex microspheres ( $F M_{i}$ Polysciences, Inc.). In all cases, Cyclidium sp. (Ciliophora, Scuticociliatida), a small (15 to $25 \mu \mathrm{m}$ ) bacterivorous ciliate previously isolated from marine tidal flat sediments and kept in the lab on a mixed bacterial diet, was used as a model grazer.

Ciliates were cultured in acid washed $250 \mathrm{ml}$ Erlenmeyer flasks with mixed bacteria grown in situ on rice medium (2 autoclaved rice grains per $150 \mathrm{ml}$ of PFW). The source of bacteria was marine intertidal sand (see 
above). At a ciliate density of $\geq 50$ cells $\mathrm{ml}^{-1}$ (exponential growth), bacterial tracers were added at $\leq 5 \%$ of total bacterial density $\left(1.38\right.$ to $1.67 \times 10^{6}$ cells $\mathrm{ml}^{-1}$ depending on the flask). These tracers were either: (1) CTC-stained bacteria prepared as above; or (2) DTAFstained bacteria prepared after Sherr et al. (1987) and Sherr \& Sherr (1993) (2 h staining at $60^{\circ} \mathrm{C}$ at $0.2 \mathrm{mg}$ $\mathrm{ml}^{-1}$ dye final concentration); or (3) FITC-stained bacteria prepared according to Monger \& Landry (1992) and González et al. (1993a) (15 min staining at $100 \mu \mathrm{g}$ $\mathrm{ml}^{-1}$ dye final concentration in $40 \mu \mathrm{g} \mathrm{ml}^{-1}$ dithioerythritol solution in PFW); or (4) FM, fluorescing bright orange latex microspheres, $0.5 \mu \mathrm{m}$ in diameter

In the course of the grazing experiments, samples from different experimental flasks were taken, preserved with ice-cold glutaraldehyde $(2 \%$ final concentration) following the recommendations of Sieracki et al. (1987), stained with DAPI as above, concentrated on 2 or $3 \mu \mathrm{m}$ pore-size black polycarbonate filters (Polysciences, Inc.), and examined under epifluorescent illumination. Under DAPI-filter set (UV excitation, see above), protozoa were located and counted; under FITC-filter set [blue excitation; Leitz filter block 513417 (390 to $490 \mathrm{~nm}$ excitation filter, $510 \mathrm{~nm}$ beam splitter, and $515 \mathrm{~nm}$ barrier filter); Zeiss filter block 9108460019 (485 nm excitation filter, $505 \mathrm{~nm}$ beam splitter, and $530 \mathrm{~nm}$ barrier filter j], the contents of their digestive vacuoles were examined, and the consumed fluorescent tracers were counted.

The grazing experiment was run in triplicate.

Protozoan growth experiment. The growth of $\mathrm{CyC}$ lidium sp. was studied on a bacterial diet with Klebsiella pneumoniae ATCC 27889 as prey. The bacteria were grown on marine agar (Difco Laboratories). The marine broth used to prepare the marine agar was diluted 50-fold against the concentration recommended by the manufacturer to prevent the predominance of large bacterial cells which are rich under typical culture conditions. Colonies were picked up from the agar surface, resuspended in PFW, vortexed, lightly sonicated ( 3 bursts of $1 \mathrm{~s}$ each), and cleansed from the medium by repetitive ( 3 cycles) resuspension in PFW/centrifugation $(13600 \times g ; 15$ min). The bacterial suspensions were divided into 2 parts, with the experimental fraction to be stained with CTC as in the bacterial growth experiment and the control fraction to be used unstained. The bacteria were inoculated into $150 \mathrm{ml}$ of PFW in acid washed $250 \mathrm{ml}$ Erlenmeyer flasks followed by the addition of Cyclidium sp. Bacterial growth in all flasks was stopped by the addition of penicillin and vancomycin (both from Sigma; final concentrations 1 and $200 \mathrm{mg} \mathrm{l}^{-1}$, respectively) according to Sherr et al. (1986). This prevented the growth of CTCstained bacteria which would otherwise lose their staining after 2 or 3 divisions. Flasks were incubated with agitation $(100 \mathrm{rpm})$ at room temperature $\left(22^{\circ} \mathrm{C}\right)$ and under a $16 \mathrm{~h}$ light $/ 8 \mathrm{~h}$ dark regime. Samples from the flasks were taken to enumerate Cyclidium $\mathrm{sp}$. and processed as in the grazing experiment. Both the experiment and control were conducted in triplicate.

Statistical analyses. Statistical analyses were performed according to Sokal \& Rohlf (1981). The Kruskal-Wallis non-parametric test was used throughout the study.

\section{RESULTS}

\section{Live fluorescent staining}

All the employed fluorescent dyes stained bacteria. The quality of staining was different depending on the stain and staining protocol.

Both HE and BCECF stained only relatively small isolated areas within bacterial cells. As a result, bacteria appeared to be stained rather weakly with the fluorescence fading within a few seconds of illumination. This made the employed staining protocols unsuitable for the purposes of this study. FITC stained bacteria well regardless of the protocol employed. Overnight incubations at high $\left(100 \mu \mathrm{g} \mathrm{ml} \mathrm{ml}^{-1}\right)$ concentration resulted in brighter cells that remained fluorescent for at least several days at room temperature. However, this protocol also resulted in rather bright non-specific staining of the detrital particles typically abundant in field samples. The level of non-specific staining diminished considerably once a lower $\left(10 \mu \mathrm{g} \mathrm{ml}^{-1}\right)$ dye concentration and shorter incubations (10 to $15 \mathrm{~min}$ ) were employed. However, the brightness of bacteria, especially that of the small ones, diminished also.

A recently introduced vital fluorescent dye, cyanoditolyl tetrazolium chloride (CTC), appeared as a promising alternative dye to prepare fluorescently labeled bacteria for grazing experiments. Each of the several dye concentrations appeared to work equally well; the lowest concentration $(0.5 \mathrm{mM}$ final) was therefore used. For optimum staining, a $2 \mathrm{~h}$ incubation was required. With this protocol, we did not find it necessary to increase the temperature to $28^{\circ} \mathrm{C}$ as recommended by the manufacturer and Rodriguez et al. (1992). Longer (overnight) incubations only slightly increased the brightness of stained cells. With the chosen protocol $10.5 \mathrm{mM}$ final dye concentration, $2 \mathrm{~h}$ staining time, room temperature), the dye readily stained $98 \pm$ (SD) $1 \%$ of cultured bacteria (data not shown). From field sediment-derived bacteria, if stained immediately upon extraction (see below for protocol), only a few percent of bacteria became stained. However, an overnight incubation $\left(22^{\circ} \mathrm{C}\right)$ of field bacteria suspended in PFW appeared to 'awaken' many cells even 
without nutrients added. The exact proportion of bacteria able to incorporate the dye after such incubation varied from sample to sample but was always $>50 \%$.

The dye accumulates in the respiring cell as water insoluble crystals which make bacteria bright red (602 nm emission maximum) under blue epifluorescent illumination (a color photograph of CTC stained bacteria can be found in Rodriguez et al. 1992). Depending on the cell activity and staining protocol, the crystals occupy varying space, from a few percent to approximately half or more of the cell volume. The fluorescence will not fade for several minutes if illuminated with a $50 \mathrm{~W}$ mercury lamp and for 15 to $30 \mathrm{~s}$ if a $100 \mathrm{~W}$ xenon lamp is used. Under regular daylight conditions and room temperature, the stained bacteria do not lose the ability to fluoresce for at least $5 \mathrm{~d}$. Preserved $(2 \%$ cold glutaraldehyde) and frozen $\left(-20^{\circ} \mathrm{C}\right)$ samples showed the same level of fluorescence after more than $3 \mathrm{wk}$ of storage.

\section{Bacterial growth experiment}

We examined initial stages, including the exponential growth phase, of bacterial growth. Both the CTCstained and unstained bacteria grew equally well (Fig. 1). There was no statistical difference between the slopes of the growth curves. We concluded that staining with CTC did not impair the ability of bacteria to grow and was probably non-toxic to them.

\section{Grazing experiment}

The protozoa grazed on all the tracers offered (Fig. 2). There was no statistically significant difference between protozoan rates as calculated on the basis of consumption of FITC-stained bacteria (alive), DTAF-stained bacteria (heat-killed), and FM (artificial prey). The numbers of the first 2 tracers steadily increased in protozoan di-

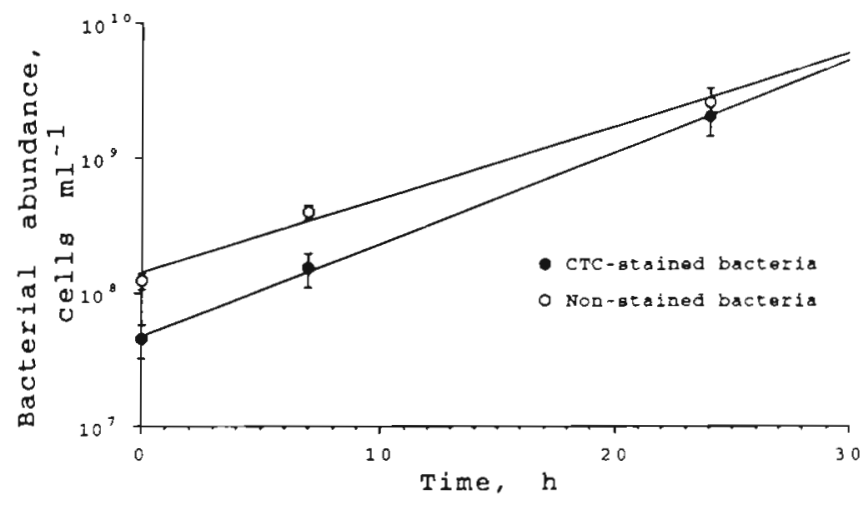

Fig. 1. Test of toxicity of CTC staining on bacterial growth

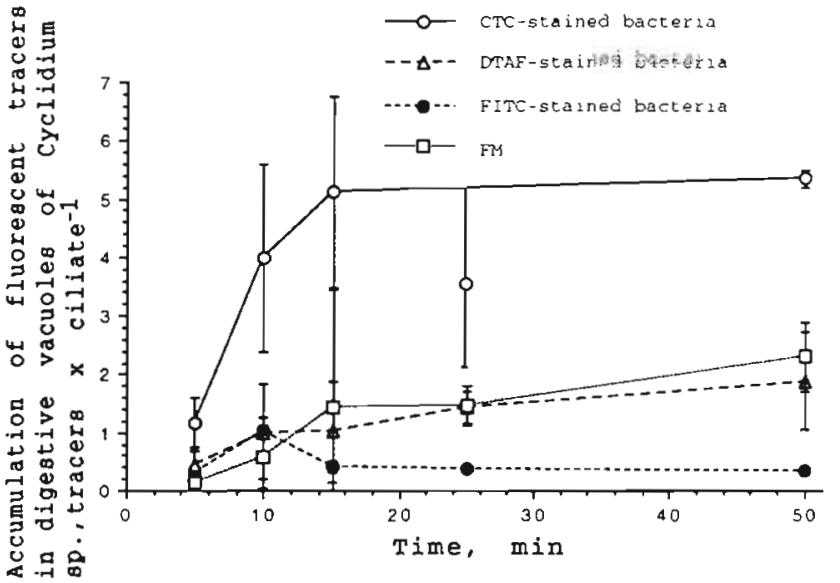

Fig. 2. Cyclidium sp. grazing on field bacteria mixed with different food tracers

gestive vacuoles from 0 to 1.8 to 2.2 per grazer after 50 min of grazing. The corresponding clearance rates stayed constant [3.9 (DTAF) and $5.9 \times 10^{-5}$ (FM) ml ciliate $\mathrm{C}^{-1} \mathrm{~h}^{-1}$ ] for the first $15 \mathrm{~min}$ of the experiment but dropped 3- to 6-fold as calculated from the data from longer incubations. The FM were always easy to distinguish as they fluoresced bright orange against DAPIcaused blue fluorescence and glutaraldehyde induced greenish fluorescence of the grazers. This was not so in the case of DTAF-and FITC-stained bacteria, especially the small ones, as the color of their fluorescence coincided with that of the grazers' bodies.

Similar to FM, the bright red fluorescing CTCstained bacteria were easy to discriminate inside the protozoa. The number of these tracers in ciliate food vacuoles grew rapidly for the first 15 min reaching $5.1 \pm(\mathrm{SE}) 1.6$ per grazer and remained essentially unchanged thereafter (Fig. 2). Considering that these tracers constituted $5 \%$ of the total number of bacteria available to protozoa, the above rate of tracer accumulation translates into a rate of 408 bacteria ciliate ${ }^{-1} \mathrm{~h}^{-1}$ of the total Cyclidium sp. bacterivory. The corresponding clearance rate varied from 1.83 to $3.21 \times 10^{-4} \mathrm{ml}$ ciliate $^{-1} \mathrm{~h}^{-1}$ during the first $15 \mathrm{~min}$ of feeding, followed by a significant (2-to 4 -fold) drop at 25 and $50 \mathrm{~min}$ incubations.

\section{Protozoan growth experiment}

Ciliates Cyclidium sp. grew equally well on CTCstained and non-stained bacteria (Fig. 3). Both the slopes of the exponential portion of the growth curves and the attained protozoan densities were statistically indistinguishable between the experiment and the control as were the degrees of bacterial disappearance due to protozoan grazing (Fig. 4). 


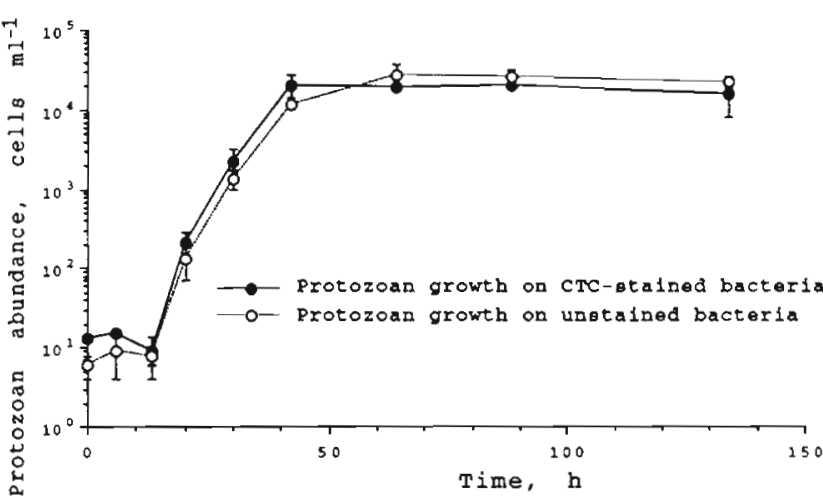

Fig. 3. Test of toxicity of CTC-stained food on protozoan growth

\section{DISCUSSION}

Both bacteria and protozoa represent important components of any aquatic community. Consequently, their interactions, including trophic interactions, may be of primary importance in community functioning. Not surprisingly, the techniques to study these interactions have been - and presently are - a focus of marine microbial ecological research (Monger \& Landry 1992, González et al. 1993a, b, Ohman 1993, Starink et al. 1994).

The approach utilizing fluorescently labeled prey, bacterial in particular, as food tracers in grazing experiments is widely used (Sherr \& Sherr 1993). A very important step in the corresponding protocol is the fluorescent bacterial staining. Ideally, an employed dye and staining protocol should be: (1) vital so as not to kill the bacteria to be stained; (2) specific to living cells so that detrital particles are not stained; (3) sufficiently bright to discern ingested FLBs in the bodies of the grazers (most preferably, FLBs should appear in specific color under epifluorescent illumination sufficiently different from those used to visualize protozoan grazers (i.e. DAPI, FITC, primulin, proflavin) as well as those inherent to grazers (red chlorophyll, orange phy-

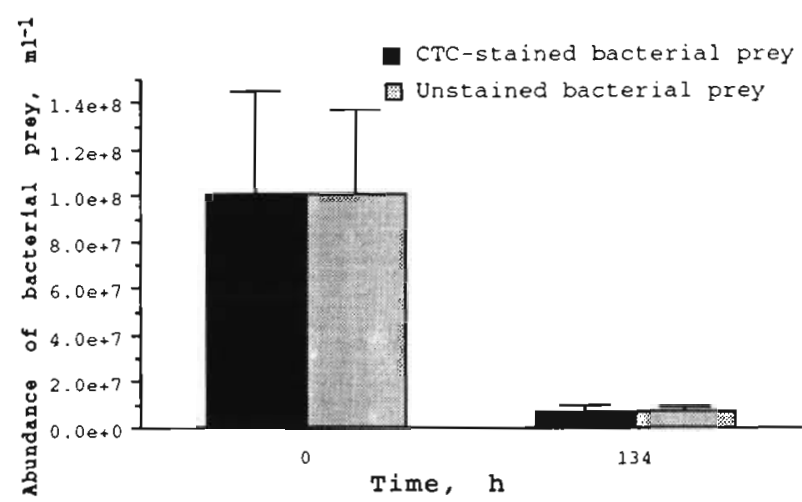

Fig. 4. Decline of bacterial abundance in Cyclidium $s p$ growth experiment (Fig. 3) due to protozoan grazing coerythrin, greenish preservative-induced cytoplasm fluorescence); (4) stable under normal light and epifluorescent illumination.

The FLB-based protozoa-bacteria grazing experiments conducted to date have almost universally employed DTAF to prepare FLBs. The dye meets requirement (4), but the other requirements are not always met: (1) non-vitality: DTAF, at least in the way it is used in grazing studies, is not a vital dye so that the DTAFstained FLBs are in fact dead (heat-killed) cells; (2) non-specificity: the dye produces strong nonspecific staining of various debris. Therefore, if field bacterial assemblages are to be used to prepare FLBs, a number of bacteria-sized detrital particles might be expected to be similar in their appearance to bacteria. The problem is most pronounced in eutrophic waters and sediments. As a result, culture-derived bacteria, often monospecific, have been largely used for FLB preparation, raising the question of how well these FLB would mimic diverse (and much smaller in size) field bacteria; (3) color requirements: in addition to non-specific staining of debris, there is another inherent DTAF disadvantage making it difficult to work with field bacterial assemblages. Many field bacteria are quite small and, if stained with DTAF (and fluoresce green), they may not be bright enough to overcome the grazer's body fluorescence (also green). The latter is greatly intensified by some fixatives, especially glutaraldehyde (E. \& B. Sherr pers. comm.). Formalin and lugol-formalin-sodium thiosulfate fixative mixtures minimize the fluorescence problem (Sherr \& Sherr 1993). The lugol-formalin approach has been shown to work as well as ice-cold glutaraldehyde in terms of preventing fixation-induced egestion of food vacuole contents (Sieracki et al. 1987, Sherr et al. 1989). However, the use of glutaraldehyde may be necessitated in sediment research by protozoan extraction procedure (S. Epstein unpubl.). More generally, the fluorescence problem is most pronounced in benthic studies. On average, benthic protozoa are many times larger than their planktonic counterparts, which results in both stronger inherent autofluorescence and stronger preservation-caused fluorescence of their bodies. Metazoan bacterivory is still more difficult to study because their bodies fluoresce in green many times brighter than even benthic protozoa.

Therefore, the use of DTAF-stained FLBs in trophic experiments necessitates several assumptions. The most important ones are concerned with potential selectivity in bacterivory. Consideration 1 is important if grazers exercise choice in consuming live versus dead and motile versus non-motile bacteria. Such selection has been suggested (Sherr et al. 1987, Landry et al. 1991, McManus \& Okubo 1991) and recently observed (Monger \& Landry 1992, González et al. 
1993a). Consideration 2 is important if grazers exercise specific, size and other forms of selection in bacterivory. Some of these forms have been unequivocally shown in a number of studies (Krambeck 1988, Chrzanowsky \& Simek 1990, González et al. 1990, Sherr et al. 1990, Epstein \& Shiaris 1992a, González et al. 1993a). This necessitates the use of field bacterial assemblages rather than cultured bacteria as a source of cells for fluorescent staining which, in at least some environments, may be difficult to achieve using DTAF (Considerations 2 and 3 ).

Recently, a vital dye, fluorescein isothiocyanate (FITC), has been used as a DTAF alternative (Monger \& Landry 1992, González et al. 1993a). Using motile bacteria as a model prey, a substantial difference was shown in protozoan grazing rates on live (FITCstained) versus killed (DTAF-stained) cells of the same strain. The introduction of FITC as a non-lethal dye has thus eliminated one of the most important drawbacks (Consideration 1) of the earlier, DTAF-based protocol. Unfortunately, Considerations 2 and 3 are as valid for FITC-as they are for DTAF-stained prey.

We conducted a search for a fluorescent dye that would satisfy all the above requirements, and found a recently introduced vital fluorescent dye, CTC, to be a promising alternative to DTAF and, under certain conditions, FITC, in grazing studies.

CTC is a respiratory dye that, in its oxidized form, is colorless, non-fluorescent, and soluble in water. Inside a respiring cell, CTC is reduced and accumulates intracellularly as CTC-formazan. The latter is insoluble and fluorescent. As non-biological reduction of CTC in field samples is probably not strong enough to produce any substantial amounts of extracellular CTC-formazan, the dye is very specific to live, metabolizing cells. It has been used previously to evaluate the number of actively respiring bacteria in environmental samples (Rodriguez et al. 1992).

The experimental results indicate that CTC-stained bacteria are: (1) alive and growing at rates identical to non-stained bacteria (Fig. 1); (2) non-toxic to protozoan grazers which grow equally well on CTC-and nonstained bacteria (Fig. 3); (3) consumed at higher rates than other bacterial and artificial tracers (Fig. 2) and apparently consumed at the same rates as non-stained bacteria (Fig. 4); (4) exhibiting a bright red fluorescence which contrasts well with the grazers' blue DAPI-caused fluorescence, glutaraldehyde-induced greenish cytoplasm fluorescence, and, in some grazers, inherent greenish autofluorescence.

The fourth advantage is particularly important for the following reason. In protozoa- and, to some extent, micrometazoa-bacteria grazing experiments that have employed fluorescently labeled prey, fluorescence microscopy was used not only to enumerate consumed tracers, but also to visualize, locate, and identify the grazers themselves. As the prey was labeled with green-fluorescing dyes (DTAF and FITC), the choice of fluorochromes to stain grazers was limited to fluorescing blue DAPI. This dye is highly specific to DNA and, at commonly used concentrations, will not resolve cytoplasm, flagella or cilia which may make it difficult to identify the grazer. This is why either elevated DAPI concentrations (Sherr et al. 1993) or less specific dyes such as FITC, primulin and proflavin, alone or in concert with DAPI (Haas 1982, Caron 1983, Sherr \& Sherr 1983, Martinussen \& Thingstad 1991), have often been used for protozoa counting purposes. This provides much better fluorescent images of, for example, protozoan bodies, cilia and flagella placement. In the authors' experience, the dual staining is particularly useful in aquatic protozoan enumeration/identification. However, the use of dual labeling in grazing studies has been precluded by the fact that the above dyes would mask DTAF- or FITC-stained prey. The red fluorescing CTC-stained prey allows blue/green dual protozoan staining, thus allowing for enumeration of consumed prey items and superior grazer identification.

Another advantage of CTC lies in its specificity to live cells. Since detrital particles are not stained unless very high dye concentrations/long incubations are used, it is possible to stain field derived, detritus bound bacteria in order to study grazing on attached bacteria. So far, this could be achieved only by a rather elaborate experimental design (Starink et al. 1994).

The color properties of CTC, advantageous in some respects, bring certain limitations to its use in prey staining. The red color of CTC-stained bacteria fluorescence is close to the color of chlorophyll/phycoerythrin fluorescence, which may make it difficult to discriminate CTC-stained bacteria inside mixotrophic grazers. In this case, FITC-stained tracers may be easier to distinguish. There is also a price to be paid for high CTC specificity, from which 2 shortcomings result. First, as only metabolically active bacteria are stained, it follows that only grazing on active bacteria can be studied. If there is a selection for active bacteria, the rates of total bacterivory may be overestimated. This may explain why Cyclidium sp. consumed CTCstained bacteria at rates higher than all the other tracers. The latter were consumed at similar rates apparently without discrimination. This corroborates well with the earlier observation that Cyclidium sp. did not discriminate between FM and live bacteria (Pace \& Bailiff 1987). Second, as not all the field bacteria were metabolically active, not all of the bacteria reduced the dye to the extent that would allow their visualization. Whereas in the water column the proportion of respiring bacteria is relatively high (Rodriguez et al. 1992), it 
is rather low in aquatic sediments. In our preliminary experiments, only a few percent of extant marine sediment bacteria incorporated substantial amounts of CTC (S. Epstein \& J. Rossel unpubl.). We found that an overnight incubation (room temperature, no nutrients added) of field-derived sediment bacteria increased the number of bacteria incorporating the dye to over $50 \%$ of the total DAPI count. Therefore, if CTC-stained bacterial tracers are made from such a mixture, up to half of the cells may not be fluorescing.

In conclusion, the new vital dye, cyanoditolyl tetrazolium chloride (CTC), has been identified as a promising stain to prepare fluorescently labeled prey for grazing experiments. Its advantages are its specificity to living cells, its non-toxicity, and its fluorescing properties. These qualities may make CTC-stained fluorescent food tracers suitable for the study of heterotrophic protozoan and micrometazoan bacterivory in aquatic communities, particularly in detritus rich eutrophic waters and sediments.

Acknowledgements. We thank Dr Sergei Sokol (Harvard Uni versity/Beth Israel Hospital, Boston, MA, USA) for allowing us to use his microscope facilities. Constructive, critical comments by 3 anonymous reviewers helped to improve and clarify the manuscript. Many thanks to Thomas Griffith (Maine Maritime Academy, Castine, ME, USA) for editing the earlier drafts. The work was financially supported by NSF Grant OCE-9217250 to S.S.E. This is contribution 208 of the Marine Science Center of the Northeastern University, Nahant, MA, USA

\section{LITERATURE CITED}

Azam F, Fenchel T, Field JG, Gray JS, Meyer-Reil LA, Thingstad F (1983) The ecological role of water column microbes in the sea. Mar Ecol Prog Ser 10:257-263

Caron D (1983) Technique for enumeration of heterotrophic and phototrophic nanoplankton, using epifluorescence microscopy, and comparison with other procedures. Appl environ Microbiol 46:491-498

Chrzanowski TH, Simek K (1990) Prey-size selection by freshwater flagellated protozoa. Limnol Oceanogr 35: $1429-1436$

Epstein SS, Rossel J (1995) Enumeration of sandy sediment bacteria: search for optimal protocol. Mar Ecol Prog Ser 117:289-298

Epstein SS, Shiaris MP (1992a) Size-selective grazing of coastal bacterioplankton by natural assemblages of pigmented flagellates, colorless flagellates, and ciliates. Microb Ecol 23:211-225

Epstein SS, Shiaris MP (1992b) The rates of microbenthosand meiobenthos bacterivory in a temperate muddy tidalflat community. Appl environ Microbiol 58:2426-2431

Fenchel T (1982) Ecology of heterotrophic microflagellates. IV. Quantitative occurrence and importance as bacterial consumers. Mar Ecol Prog Ser 9:35-42

González JM, Sherr EB, Sherr BF (1990) Size-selective grazing on bacteria by natural assemblages of estuarine flagellates and ciliates. Appl environ Microbiol 56:583-589

González JM, Sherr EB, Sherr BF (1993a) Differential feeding by marine flagellates on growing versus starving, and on motile versus nonmotile, bacterial prey. Mar Ecol Prog Ser 102:257-267

González JM, Sherr BF, Sherr EB (1993b) Digestive enzyme activity as a quantitative measure of protistan grazing: the acid lysozyme assay for bacterivory. Mar Ecol Prog Ser 100:197-206

Haas LW (1982) Improved fluorescence microscopy for observing planktonic micro-organsism. Ann Inst Oceanogr 58(Suppl):261-268

Hondeveld BJM, Bak RPM, van Duyl FC (1992) Bacterivory by heterotrophic nanoflagellates in marine sediments measured by uptake of fluorescently labeled bacteria. Mar Ecol Prog Ser 89:63-71

Kemp PF (1988) Bacterivory by benthic ciliates: significance as a carbon source and impact on sediment bacteria. Mar Ecol Prog Ser 49:163-169

Kemp PF (1990) The fate of benthic bacterial production. Rev aquat $S c i$ 2:109-124

Krambeck C (1988) Control of bacterioplankton structures by grazing and nutrient supply during the decline of an algal bloom. Verh int Verein theor angew Limnol 23:496-502

Landry MR, Lehnerfournier JM, Sundstrom JA, Fagerness VL, Selph KE (1991) Discrimination between living and heat-killed prey by a marine zooflagellate, Paraphysomonas vestita (Stokes). J exp mar Biol Ecol 146:139-152

Martinussen I, Thingstad TF (1991) A simple double-staining technique for simultaneous quantification of auto-and heterotrophic nano- and picoplankton. Mar microb Food Webs 5:5-11

McManus GB, Fuhrman JA (1988) Control of bacterioplankton populations: measurement and significance of grazing. Hydrobiologia 159:51-62

McManus GB, Okubo A (1991) On the use of surrogate food particles to measure protistan ingestion. Limnol Oceanogr 36:613-617

Monger BC, Landry MR (1992) Size-selective grazing by heterotrophic nanoflagellates: an analysis using live-stained bacteria and dual-beam flow cytometry. Arch Hydrobiol Beih Ergebn Limnol 37:173-185

Ohman MD (1993) Predation on planktonic protists assessed by immunochemical assays. In: Kemp PF, Sherr BF. Sherr $\mathrm{EB}$, Cole JJ (eds) Aquatic microbial ecology. Lewis Publishers, CRC Press, Boca Raton, FL, p 731-738

Pace ML (1988) Bacterial mortality and the fate of bacterial production. Hydrobiologia 159:41-49

Pace ML, Bailiff MD (1987) Evaluation of a fluorescent microsphere technique for measuring grazing rates of phagotrophic microorganisms. Mar Ecol Prog Ser 40:185-193

Porter KG, Feig YC (1980) The use of DAPI for identifying and counting aquatic microflora. Limnol Oceanogr 25:943-948

Rodriguez GG, Phipps D, Ishiguro K, Ridgway HF (1992) Use of a fluorescent redox probe for direct visualization of actively respiring bacteria. Appl environ Microbiol 58: $1801-1808$

Schallenberg M, Kalff J, Rasmussen JB (1989) Solutions to problems in enumerating sediment bacteria by direct counts. Appl environ Microbiol 55:1214-1219

Sherr BF, Sherr EB (1984) Role of heterotrophic protozoa in carbon and energy flow in aquatic ecosystems. In: Klug M, Reddy CA (eds) Current prospectives in microbial ecology. American Society for Microbiology, Washington, DC, p $412-423$

Sherr BF, Sherr EB, Andrew TL, Fallon RD, Newell SY (1986) Trophic interactions between heterotrophic protozoa and bacterioplankton in estuarine water analyzed with selective metabolic inhibitors. Mar Ecol Prog Ser 32:169-179 
Sherr BF, Sherr EB, Fallon RD (1987) Use of monodispersed, fluorescently labeled bacteria to estimate in situ protozoan bacterivory. Appl environ Microbiol 53:958-965

Sherr BF, Sherr EB, McDaniel J, González J, Hanson R (1990) Size-selective grazing by bacterivores protozoa: implication for bacterial production. EOS 71:162

Sherr BF, Sherr EB, Pedrós-Alió C (1989) Simultaneous measurement of bacterioplankton production and protozoan bacterivory in estuarine water. Mar Ecol Prog Ser 54 209-219

Sherr EB, Caron DA, Sherr BF (1993) Staining of heterotrophic protists for visualization via epifluorescence microscopy. In: Kemp PF, Sherr BF, Sherr EB, Cole JJ (eds) Aquatic microbial ecology. Lewis Publishers, CRC Press, Boca Raton, FL, p 213-227

Sherr EB, Sherr BF (1983) Double-staining epifluorescence technique to assess frequency of dividing cells and bac-

This article was submitted to the editor terivory in natural populations of heterotrophic microprotozoa. Appl environ Microbiol 46:1388-1393

Sherr EB, Sherr BF (1993) Protistan grazing rates via uptake of fluorescently labeled prey. In: Kemp PF, Sherr BF, Sherr EB, Cole JJ (eds) Aquatic microbial ecology. Lewis Publishers, CRC Press, Boca Raton, FL, p 695-701

Sieracki ME, Haas LW, Caron DA, Lessard EJ (1987) The effect of fixation on particle retention by microflagellates: underestimation of grazing rates. Mar Ecol Prog Ser 38: $251-258$

Sokal RR, Rohlf FJ (1981) Biometry, 2nd edn. WH Freeman \& Co, New York

Starink M, Krylova IN, Bär-Gilissen MJ, Bak RPM, Cappenberg TE (1994) Rates of benthic protozoan grazing on free and attached sediment bacteria measured with fluorescently stained sediment. Appl environ Microbiol 60: 2259-2264

Manuscript first received: December 5, 1994

Revised version accepted: May 22, 1995 